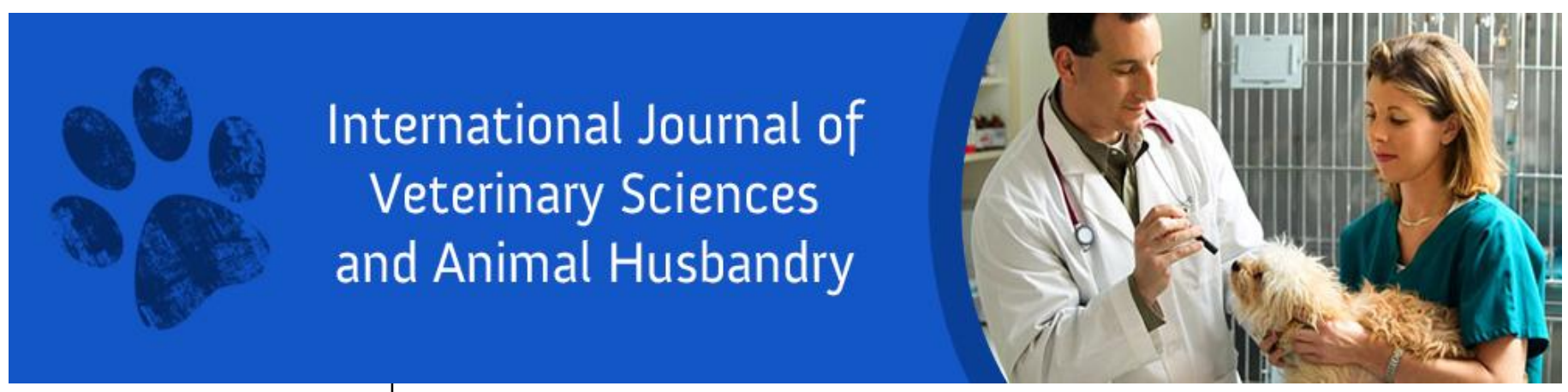

ISSN: $2456-2912$

VET 2019; 4(3): 05-08 (C) 2019 VET

www.veterinarypaper.com

Received: 04-03-2019

Accepted: 06-04-2019

\section{Mustafa Kockaya}

Department of Veterinary

Physiology, Faculty of

Veterinary Medicine, Sivas

Cumhuriyet University, Sivas,

Turkey
Correspondence

\section{Mustafa Kockaya}

Department of Veterinary

Physiology, Faculty of

Veterinary Medicine, Sivas

Cumhuriyet University, Sivas,

Turkey

\section{Comparisons of some blood hematological levels and biochemical parameters in pregnant and non-pregnant Kangal shepherd dogs}

\author{
Mustafa Kockaya
}

DOI: $\underline{\text { https://doi.org/10.22271/veterinary.2019.v4.i3a.184 }}$

Abstract

The aim of this study is to compare some blood hematological levels and biochemical parameters obtained from pregnant and non-pregnant Kangal shepherd dogs. Blood samples were collected from 24 pregnant and 24 non-pregnant Kangal shepherd dogs that were aged between 3 to 5 years. Pregnant dogs were in their 35 to 52 days of their pregnancy. Non-pregnant dogs were beyond 30 or more days in their dioestrus. Automatic hemocytometer device was used to determine leucocyte count, erythrocyte count, hemoglobin, hematocrit, platelets, mean erythrocyte hemoglobin, mean erythrocyte hemoglobin concentration and mean erythrocyte volume levels in collected blood samples. Serum levels of total cholesterol, triglyceride, iron, high density lipoprotein and low density lipoprotein parameters were determined using biochemical analyzer device. Results of the study were presented significant increases for iron, hemoglobin, mean erythrocyte hemoglobin concentration and mean erythrocyte hemoglobin parameters in non-pregnant dogs and for cholesterol, low density lipoprotein and triglyceride parameters in pregnant dogs. Statistical significance was not determined for other parameters.

Keywords: Kangal shepherd dog, pregnancy, non-pregnancy, blood parameter

\section{Introduction}

Domestic dogs, which are descendants of the extinct grey wolf (Canis lupus) genetically predicted to be first used by humans in Eastern Asia 15 to 100 thousands years ago (Jensen, 2007) ${ }^{[9]}$. It was reported that breeds with herd protection capabilities were among the first dogs used in domesticated dog breeds (Sims and Dawydiak, 1990) ${ }^{[21]}$. The Kangal shepherd dog breed is greatly preferred for both herd protection and watchdog duties in Turkey as well as in many other countries in the world (Koçkaya and Şireli, 2015) ${ }^{[13]}$. This breed is called the "Kangal shepherd dog" due to the intense and the most typical presence of this breed in the Kangal town of the Sivas province in Turkey (Akçay, 2005; Özbeyaz, 1994; Y1lmaz, 2008) ${ }^{[1,}$ $17,25]$. Due to the great adaptability of these dogs, they are raised in many different countries, but, the literature about the pregnancy blood parameters for this breed was found insufficient (Reed, 2003) ${ }^{[19]}$.

A typical pregnancy duration in dogs is 63 days. Delivery is considered as normal if it happens within 7 days earlier or later. Survival rates for pups were reported to be decreased in the case of significant changes in pregnancy duration (Taylor, 1993) ${ }^{[23]}$. Pregnancy is not visible in dogs until the $4^{\text {th }}$ week. After the $4^{\text {th }}$ week of the pregnancy, the abdomen starts to become enlarged and saggy, and also the udder starts to become enlarged. Towards the end of pregnancy, breast milk starts to flow from the udder (Horoz et al., 1996) ${ }^{[8]}$. Physical activity decreases in female dogs as the pregnancy progresses (Altınköprü, 1993) ${ }^{[3]}$. When the delivery time arrives, a pregnant dog starts to search for a safe spot, and the delivery generally occurs either at night or early in the morning (Browlie, 1988) ${ }^{[4]}$. Certain changes in both blood composition and biochemical parameters become apparent in dogs during the healthy pregnancy duration. Abnormal increases or decreases in these parameters during pregnancy are recognized as risk factors for some physiological disorders. Among these physiological disorders are anemia, hypertension, premature delivery, and lower birth weights. Monitoring the hematological and biochemical parameters during pregnancy is considered to be important for the healthy maintenance of pregnancy and for fetal development. 
As with the other animal species, hematological parameters show great differences in dogs. These differences stem from various factors, including age, genetics, breed, pregnancy, and environmental factors. Even though there are many different studies regarding normal hematological values in Kangal shepherd dogs (Çınar et al., 2010; Kalaycıoğlu et al., 1995; Koçkaya et al., 2017) [6, 11, 14], the literature about hematological values during pregnancy is insufficient (Kaymaz and Baştan, 1997; Rushton, 1984) ${ }^{[12,20]}$.

The aim of the study was to compare some hematological and biochemical parameters obtained from pregnant and nonpregnant Kangal shepherd dogs.

\section{Materials and Methods}

Animal experimentations approval for the study was granted by the Local Ethics Committee for Animal Experimentations of Cumhuriyet University with issue number of 65202830050.04.04-96 in October 28, 2016.

\subsection{Animals}

Kangal shepherd dogs used in the study were obtained from breeders in the Sivas province of Turkey, and they comprised 24 pregnant and 24 non-pregnant dogs aged between 3 and 5 years. The pregnant dogs were chosen in their 35 to 52 days into pregnancy. The non-pregnant dogs were chosen from dogs that were into 30 days or more in their dioestrus periods. The dogs were selected on the basis of anamnesis provided by their breeders and ultrasonography results.

\subsection{Blood sampling}

During the course of the study, the animals were kept in their familiar environment and allowed to perform their routines in order to prevent stress and potential alterations in their hematological parameters. Establishments were chosen according to having to offer a similar dietary provisions to dogs in order to prevent dietary changes in both hematological and biochemical parameters.

Blood samples from each dog were collected from antebrachial cephalic vena into two tubes which were lithium heparin containing tubes and yellow capped anticoagulantfree gel coated biochemistry tubes. Stress occurrence in dogs was prevented by prior familiarization of dogs to blood sampling and by familiarization of dogs to the person who will collect samples. Blood samples were delivered into the laboratory in shortest time possible. Blood samples were centrifuged for $10 \mathrm{~min}$ at $4000 \mathrm{rpm}$ for obtaining serums. Obtained serums were stored at $-20^{\circ} \mathrm{C}$ until the analysis. Biochemistry analyzer device (Mindray BS200, Mindray, P.R.C.) was used to determine serum total cholesterol, triglyceride, iron (Fe), high density lipoprotein (HDL), and low density lipoprotein (LDL) levels. Automatic hemocytometer device (Hematologic Analyzer System 9000, Serono Diagnostics) was used to determine hematological parameters.

\subsection{Statistics}

Dogs were divised into 2 study groups as pregnant dogs and non-pregnants dogs, and intergroup statistical analyses were conducted by using Mann-Whitney U test. Statistics were performed by using SPSS v.15 for Windows (SPSS Inc, IBM, USA) ${ }^{[22]}$ software suite.

\section{Results}

Obtained hematological values from pregnant and nonpregnant Kangal shepherd dogs were presented in Table 1. Hemoglobin (HGB), mean erythrocyte hemoglobin concentration (MCHC) and mean erythrocyte hemoglobin $(\mathrm{MCH})$ values for hematological comparisons of study groups were determined as statistically significant $(P<0,001$; $P<0.01)$. These values were observed as higher in nonpregnant dogs compared to pregnant dogs.

Table 1: Determined hematological values in study groups.

\begin{tabular}{|c|c|c|c|}
\hline \multicolumn{4}{|c|}{ Groups } \\
\hline Parameter & Pregnant (n=24) median & Non-Pregnant $(\mathbf{n = 2 4})$ median & P-Value \\
\hline HGB $(\mathrm{g} / \mathrm{dL})$ & 10.65 & 12.95 & $* * *$ \\
\hline WBC $\left(10^{9} / \mathrm{L}\right)$ & 12.7 & 12.5 & Nss. \\
\hline RBC $\left(10^{12} / \mathrm{L}\right)$ & 5.96 & 6.23 & Nss. \\
\hline HCT $(\mathrm{fL})$ & 34.95 & 36.8 & Nss. \\
\hline MCV & 64.45 & 65.65 & Nss. \\
\hline MCH $(\mathrm{pg})$ & 22.15 & 22.85 & $* *$ \\
\hline MCHC $(\mathrm{g} / \mathrm{dL})$ & 33.45 & 34.6 & $* * *$ \\
\hline PLT $\left(10^{9} / \mathrm{L}\right)$ & 316 & 312 & Nss. \\
\hline
\end{tabular}

L:liter, dL: deciliter, fL: femtoliter, g: gram, pg: picogram

Nss: statistically insignificant $(\mathrm{P}>0.05), * *: P<0.01 * * *: P<0.001$

Obtained serum biochemistry values from pregnant and nonpregnant Kangal shepherd dogs were presented in Table 2. Intergroup serum biochemistry comparisons revealed that all values excluding HDL (Fe, triglyceride, LDL, and cholesterol) were determined as statistically significant
$(P<0.001 ; \quad P<0.01 ; \quad P<0.05)$. Triglyceride, LDL, and cholesterol values were determined as higher in pregnant dogs whereas only $\mathrm{Fe}$ values were determined as higher in nonpregnant dogs.

Table 2: Determined serum biochemistry values in study groups

\begin{tabular}{|c|c|c|c|}
\hline \multicolumn{3}{|c|}{ Groups } & P-Value \\
\hline Parameter & Pregnant $(\mathbf{n = 2 4})$ median & Non-Pregnant $(\mathbf{n = 2 4 )}$ median & $*$ \\
\hline Cholesterol $(\mathrm{mg} / \mathrm{dL})$ & 160.16 & 159.16 & Nss. \\
\hline HDL & 99.33 & 99.33 & $* *$ \\
\hline LDL & 15.89 & 15.33 & $* * *$ \\
\hline Fe $(\mu \mathrm{g} / \mathrm{dL})$ & 21.21 & 22.05 & $* * *$ \\
\hline Triglyceride $(\mathrm{mg} / \mathrm{dL})$ & 55.98 & 53.07 & \\
\hline
\end{tabular}




\section{Discussion}

Even though there are many different studies regarding the normal hematological values in Kangal shepherd dogs (Çınar et al., 2010; Kalaycioğlu et al., 1995; Koçkaya et al., 2017) ${ }^{[6,}$ $11,14]$, the literature about hematological values during the pregnancy was insufficient (Kaymaz and Baştan, 1997; Rushton, 1984) ${ }^{[12,20]}$. Therefore, results of this study would be fulfilling an important gap in literature by comparing hematological parameters of Kangal shepherd dogs both in pregnancy and dioestrus periods.

HGB values in the study were assessed as $12.95 \mathrm{~g} / \mathrm{dL}$ and $10.65 \mathrm{~g} / \mathrm{dL}$ in non-pregnant and pregnant Kangal shepherd dogs, respectively. Statistically significant decreases in HGB values of pregnant dogs $(P<0.001)$ were thought to be associated with the increase of plasma volume exceeding the erythrocyte mass index in pregnant dogs. Obtained result was in accordance with the other studies (Concannon et al., 1977; Rushton, 1984) ${ }^{[5,20]}$.

$\mathrm{MCH}$ and $\mathrm{MCHC}$ values were determined in non-pregnant Kangal shepherd dogs as 22.85 pg and $34.6 \mathrm{~g} / \mathrm{dL}$, respectively. Same values were assessed in pregnant dogs as $22.15 \mathrm{pg}$ and $33.45 \mathrm{~g} / \mathrm{dL}$, respectively. Statistically significant decreases in MCHC $(P<0.001)$ and $\mathrm{MCH}(P<0.01)$ in pregnant dogs were though to be associated with the decreases in hemoglobin levels due to iron deficiency. These results were similar to results provided from other studies (Allard et al., 1989; Kaymaz and Baştan, 1997; Milman et al., 2000) ${ }^{[2,12,15] .}$.

Serum Fe and ferritin levels, and total iron binding capacity in serum become decreased during the pregnancy. Serum Fe levels in the study were determined as $22.05 \mu \mathrm{g} / \mathrm{dL}$ and 21.21 $\mu \mathrm{g} / \mathrm{dL}$ in non-pregnant and pregnant Kangal shepherd dogs, respectively. Statistically significant decreases in serum $\mathrm{Fe}$ levels in pregnant dogs $(P<0.001)$ were thought to be associated with the expenditure of reserved iron in the body for fetal development and placenta maintenance. This result was found as similar to other studies (Mungan, 2002; Palmer et al., 1986; Truswell, 1985) [16, 18, 24].

Plasma LDL levels are progressively increasing during the normal pregnancy, and this increase manifests itself in increases in cholesterol and triglyceride levels. Estrogen is thought to be playing major role in these changes of lipoprotein levels during the pregnancy. Increase in placental lipoprotein lipase activity during the pregnancy facilitates the transfer of maternal lipids into fetus through physiological adaptation. Serum cholesterol, triglyceride, and LDL levels were determined in non-pregnant Kangal shepherd dogs as $159.16 \mathrm{mg} / \mathrm{dL}, 53.07 \mathrm{mg} / \mathrm{dL}$, and $15.33 \mathrm{mg} / \mathrm{dL}$, respectively. These values were determined in pregnant dogs as 160.16 $\mathrm{mg} / \mathrm{dL}, \quad 55.98 \mathrm{mg} / \mathrm{dL}$, and $15.89 \mathrm{mg} / \mathrm{dL}$, respectively. Statistically significant increases in serum cholesterol $(P<0.05)$, triglyceride $(P<0.001)$, and in LDL $(P<0.01)$ levels in pregnant dogs were thought to be associated with the mechanism of estrogen in pregnant dogs. These results were in accordance with the previous studies (Herrera, 2002; Jimenez et al., 1988) ${ }^{[7,10]}$.

\section{Conclusions}

It was assessed from the results that $\mathrm{HGB}, \mathrm{MCH}$, and $\mathrm{MCHC}$ levels were found to be significantly lower in pregnant Kangal shepherd dogs compared to non-pregnant dogs, and these results were associated with the decrease in Fe levels. Decrease in serum Fe levels in pregnant dogs is an important indicator of reserved Fe depletion. Therefore, it is thought that monitoring the Fe levels during the pregnancy would be beneficial for maintaining a healthy pregnancy duration.

It was determined from the results that serum cholesterol, triglyceride, and LDL levels in pregnant Kangal shepherd dogs were significantly higher compared to non-pregnant dogs. Therefore, it would be important to control dietary cholesterol context of pregnant dogs for maintaining a healthy pregnancy.

In conclusion, certain changes in blood hematological parameters in pregnant Kangal shepherd dogs were determined, and monitoring these parameters for the duration of the pregnancy in order to maintain a healthy pregnancy was thought be beneficial. Additionally, it can be recommended to take into consideration of these hematological parameters in pregnant dogs in cases of treatments and operations.

\section{List of abbreviations}

WBC: Leucocyte

RBC: Erythrocyte

HGB: Hemoglobin

HCT: Hematocrit

PLT: Platelets

MCH: Mean Erythrocyte Hemoglobin

MCHC: Mean Erythrocyte Hemoglobin Concentration

MCV: Mean Erythrocyte Volume

Fe: Iron

HDL: High Density Lipoprotein

LDL: Low Density Lipoprotein

L:liter

dL: deciliter

fL: femtoliter

g: gram

mg: milligram

$\mu \mathrm{g}$ : microgram

pg: picogram

Nss: statistically insignificant

\section{Acknowledgements}

This study will be presented as an oral presentation at the $2^{\text {nd }}$ International Scientific and Vocational Studies Congress Health and Sport Sciences (BILMES HL-SP 2018), 5-8 July 2018, Ürgüp, Nevşehir, Turkey.

\section{Ethics approval and consent to participate}

Approval for animal experimentations the study was granted by the Local Ethics Committee for Animal Experimentation of Cumhuriyet University permit no 65202830-050.04.04-96 issued on 28 October 2016. Written informed consent was obtained from the dogs' owners for publication of this manuscript.

\section{Funding}

This work was supported by the Scientific Research Project Fund of Cumhuriyet University under project number V-061.

\section{Availability of data and materials}

The datasets used and analyzed during the current study are available from the corresponding author on reasonable request.

\section{Author contributions}

MK conceived and designed the study. MK collected the samples and performed the analysis. MK write manuscript. 
12. Consent for publication

All data obtained from this work were approved by author for publication.

\section{Competing Interest}

There is no conflict of interest in this work.

\section{References}

1. Akçay E. Unique animals of Anatolia: Kangal shepherd dogs. Journal of Turkish Veterinary Medical Society. 2005; 76(3, 4):72-74.

2. Allard RL, Carlos AD, Faltin E. Canine Hematological Changes during Gestation and Lactation. Comp Anim Pract. 1989; 19(3):3-6.

3. Altınköprü T. Dog Nutrition. Dog World. İstanbul, 1993, 110-120.

4. Browlie S. The Adult Dog. Dog Care. London, 1988, 72.

5. Concannon P, Powers ME, Holder W. Pregnancy and parturition in the bitch. Biol Reprod. 1997; 16:517-526.

6. Çınar M, Erat S, Arıkan Ş, Mamak N, Oğrak YZ, Güzel M. Kangal Köpeklerinde Bazı Biyokimyasal Parametreler Üzerine Yaş ve Cinsiyetin Etkisi. Erciyes Üniversitesi Veteriner Fakültesi Dergisi. 2010; 7(2):109116.

7. Herrera E. Lipid metabolism in pregnancy and its consequences in the fetus and newborn. Endocrine by Humana Press Inc. 2002; 19(1):43-55.

8. Horoz H, Ekici H, Konuk CS, Kaşıkçı G. Gebe Köpeklerin Bakım ve Beslenmeleri. Journal of the Faculty of Veterinary Medicine, İstanbul University. 1996; 22(2):371-377.

9. Jensen P. The Behavioural Biology of Dogs. CAB International, Cromwell Press, Oxfordshire, UK, 2007.

10. Jimenez SM, Pocovi M, Ramon-Caja J. Longutudinal study of plasma lipids and lipoprotein cholesterol in normal pregnancy and puerperium. Gynecol Obstet Invest. 1988; 25:158-164.

11. Kalaycığlu L, Nizamoğlu M, Altunok V. Sağlıklı Kangal Köpeklerinde Kanda Bazı Biyokimyasal Parametreler. Eurasian Journal of Veterinary Sciences. 1995; 11(1):47-49.

12. Kaymaz M, Baştan A. Gebe Köpeklerde Gözlenen Hematolojik Değişiklikler. Kafkas Üniversitesi Veteriner Fakültesi Dergisi. 1997; 3(2):195-200.

13. Koçkaya M, Şireli M. Kangal Çoban Köpeklerinin Farklı Hayvan Sürülerinde Gösterdikleri Davranışsal ve Fizyolojik Değişkenlerin Karşılaştırılması. Ankara Üniversitesi Veteriner Fakültesi Dergisi. 2015; 62:261267.

14. Koçkaya M, Şireli M, Özşensoy Y. Sürü Koruma Görevi Yapan ve Kulübe Şartlarında Tutulan Kangal Köpeklerinin Kan Hematolojik Düzeylerinin Karşılaştırılması. Atatürk Üniversitesi Veteriner Bilimleri Dergisi. 2017; 12(1):28-33.

15. Milman N, Byg KE, Agger AO. Hemoglobin and erythrocyte indices during normal pregnancy and postpartum in 206 women with and without iron supplementation. Acta Anaesthesiol Scand. 2000; 79:8998.

16. Mungan T. Gebelikte kansızlık (anemi) ve demir eksikliği. Actual Medicine. 2002; 38:6-30.

17. Özbeyaz C. Kangal köpeklerinde bazı morfolojik özellikler. Journal of Lalahan Livestock Research Institute. 1994; 34(1, 2):38-46.
18. Palmer SM, Sherrill J, Morrison JC. Diseases of the blood, In: Danfort DN, Scott JR, eds. Obstetrics and gynecology. 5 th ed, Philadelpia. J.B. Lipincott, 1986, 531-538.

19. Reed S. İngiltere ve Avrupa'da Türk Köpekleri. 1. Uluslararası Kangal Köpeği Sempozyumu Bildirisi, Sivas, 2003.

20. Rushton B. Canine red blood cell results. In Rushton B eds. Veterinary Laboratory Data. BVA Publications. Edinburgh, 1984, 35-37.

21. Sims DE, Dawydiak O. Livestock Protection Dogs, Selection, Care and Training, Otr Publication, Centreville, 1990.

22. SPSS Inc. SPSS 15.0 for Windows Evalution Version. 2006.

23. Taylor D. Gebelik. Köpek bakımı. Transleted; Ziya Kutemin. Esher Kutemin. İstanbul, 1993, 192-197.

24. Truswell AS. ABC of nutrition. Nutrition for pregnancy. British Medical Journal. 1985; 291(6490):263-66.

25. Yılmaz O. Kangal (karabaş) Türk Çoban Köpeği. Bilge Kültür Sanat (ISBN 978-9944-425-93-3). İstanbul, 2008. 